\title{
Awareness and Practice of Prevention of Myocardial Infarction among Hypertensive Patients: Cross Sectional Study in a Tertiary Cardiac Centre of Nepal
}

\author{
Asmita Adhikari, ${ }^{1}$ Buna Bhandari ${ }^{2}$
}

\author{
${ }^{1}$ Kathmandu Medical College, Sinamangal, Kathmandu, Nepal \\ ${ }^{2}$ Department of Community Medicine and Public Health, Tribhuvan University Institute of Medicine, Maharajgunj, Kathmandu,Nepal
}

Corresponding author: Buna Bhandari

Department of Community Medicine and Public Health,

Maharajgunj Medical Campus, Tribhuvan University Institute of Medicine,

Email Address: bhbuna@iom.edu.np

Abstract

Background and Aims: Hypertension is one of the emerging public health problems in developing country like Nepal. Among complications of hypertension, Myocardial Infarction is most distressing. Although, myocardial infarction is life threatening disease, it is yet preventable. Good knowledge and practice is required for prevention and control of myocardial infarction. Therefore, this study intended to assess knowledge and practice of hypertensive patients regarding prevention of myocardial infarction.

Methods: : Hospital based cross- sectional study was conducted among ninety-six hypertensive patients in outpatient department of Sahid Gangalal National Heart Centre, Nepal. Purposive sampling method was used to select calculated number of study participants. Data was collected by interview method using structured questionnaire and descriptive and inferential statistics was used to analyze the data.

Results: More than half of the participants $(60.4 \%)$ had high level of knowledge of prevention of myocardial infarction whereas $39.6 \%$ had low level of knowledge. Similarly, $57.3 \%$ had good practice; however, $42.7 \%$ had poor practice. This study found significant association of knowledge with gender, education and socio-economic status. In the same manner, there was significant association of practice with ethnicity and awareness of disease.

Conclusion: Only around half of the hypertensive patients had good knowledge and practice of the prevention of myocardial infraction. Therefore, awareness level should be increased and identified factors needs to be addressed.

Keywords: Awareness; Hypertension; Myocardial Infarction; Practice; Prevention.

\section{Introduction}

Hypertension is a emerging public health challenge because of its increasing burden and being risk factor for many diseases. ${ }^{1}$ It is a major risk factor of cardiovascular disease (CVD), which causes $45 \%$ of mortality and morbidity globally. ${ }^{2}$ Importantly, it is a prevailing risk factor for Myocardial Infraction (MI) in the general population. ${ }^{3}$ CVDs are expected to be the major causes of morbidity and mortality in many developing countries of the world by $2020,{ }^{4}$ yet it is preventable. ${ }^{5}$

Knowledge about prevention and control of complication especially MI is crucial. It has been reported that South Asians have a very poor degree of knowledge regarding coronary heart disease. ${ }^{6}$ In Nepal, people have very basic ideas about MI but the detail study on this topic is still required. ${ }^{7}$

Therefore, this study aimed to identify the level of knowledge and the practice of hypertensive patients for the prevention of myocardial infarction.

\section{METHODS}

Hospital based cross-sectional study was conducted among hypertensive patients attending in Outpatient Department (OPD) of Sahid Gangalal National Heart Centre (SGNHC), Nepal in the duration of six weeks. Non-probability purposive sampling method was used to select hypertensive patients presenting in the OPD of SGNHC for the study. Ninety-six previously diagnosed hypertensive patients were taken for the study which was calculated by using $\mathrm{z}^{2} \mathrm{pq} / \mathrm{d}^{2}$, assuming prevalence of knowledge and practice $50 \%$ in $95 \%$ CI and $20 \%$ allowable error. Structured questionnaire on (knowledge and practice) were used to collect data through interview method. There were total twelve questions about knowledge and thirteen questions about practice so total knowledge score was 12 and 13 for practice. Mean score of knowledge (8.29) and practice (7.94) was taken for categorization. If knowledge score obtained by the participants was above mean score then it was categorized as high level knowledge and if it was below mean score then it was graded as low level knowledge. Similarly, if the practice score was above mean then it was categorized as good practice and if it was less than mean, it was graded as poor practice. Ethnicity was categorized as Dalits, Disadvantaged Janjatis, Disadvantaged non-dalit Terai caste groups, Religious Minorities, and Relatively Advantaged Janjatis and Upper Caste group according to caste classification card system Government of Nepal. Those participants who could read and write were taken as literate and those who were unable to do so were taken as illiterate. Kuppuswamy's socio-economic status scale ${ }^{8}$ was used for classification of socio-economic status. Data was analyzed in SPSS 20 version using descriptive (mean and standard deviation) and analytical (Chi square test) statistics. Approval was taken from ethical review board of SGNHC before conducting study and informed consent was also taken from each participants. 


\section{RESULTS}

Out of total hypertensive respondents, more than half $(60.4 \%)$ had high level of knowledge whereas 39.6\% had low level of knowledge regarding prevention of MI. Similarly, $57.3 \%$ had good practice and were taking the appropriate preventive measures of $M I$, though, $42.7 \%$ had poor practice as shown in the table no 1 .

Table 1: Level of knowledge and practice (n=96)
\begin{tabular}{|l|c|c|l|c|c|}
\hline Level of knowledge & Frequency $(\mathrm{n})$ & Percentage $(\%)$ & Level of practice & Frequency (n) & Percentage $(\%)$ \\
\hline High level $(>8.29)$ & 58 & 60.4 & Good $(>7.94)$ & 55 & 57.3 \\
\hline Low level $(<8.29)$ & 38 & 39.6 & Poor $(<7.94)$ & 41 & 42.7 \\
\hline Total & 96 & 100.0 & Total & 96 & 100.0 \\
\hline Mean \pm SD: $8.29 \pm 2.03$ & & Mean \pm SD : $7.94 \pm 1.35$ & & \\
\hline
\end{tabular}

This study revealed that knowledge level was significantly $(\mathrm{P}=0.002)$ higher among female $(74.1 \%)$ than to male (42.9\%). In the same manner, literate participants $(69.9 \%)$ were significantly $(\mathrm{P}=<0.001)$ more aware about the prevention of $\mathrm{MI}$ compared to illiterate participants. Around three fourth (70.15\%) of participants, having high level of knowledge, were from upper class and rest $(37.93 \%)$ were from lower class as shown in table no 2 .

More than half of the respondents (66.67\%) from upper caste (Brahmin and Chettri) had good practice of prevention of MI $(\mathrm{P}=0.012)$ compared to relatively advantaged Janajatis
$(32 \%)$ and others $(64.29 \%)$ caste. Moreover, those participants who were involved in awareness programs of prevention of $\mathrm{MI}$ previously, (86.67\%) had good practice of prevention of $\mathrm{MI}(\mathrm{P}=$ 0.012 ) than the participants not involved in such programs earlier $(51.85 \%)$ as presented in table no 3 .

This study showed that the maximum numbers of respondents were overweight (49\%) followed by obese $(32.3 \%)$ and normal weight $(17.7 \%)$ respectively. The calculated mean Body Mass Index (BMI) was 26.64 and standard deviation was 4.07. Out of the total respondents, $86(89.6 \%)$ were at risk of cardiovascular disease according to increased waist hip ratio.

\begin{tabular}{|c|c|c|c|c|c|}
\hline & \multirow{2}{*}{ Variables } & \multicolumn{2}{|c|}{ Grading of knowledge } & \multirow{2}{*}{ Total (\%) } & \multirow{2}{*}{$\mathrm{P}$ valuea } \\
\hline & & High (\%) & Low (\%) & & \\
\hline Age category & $\begin{array}{l}<50 \text { years } \\
>50 \text { years }\end{array}$ & $\begin{array}{l}22(68.75) \\
36(56.25)\end{array}$ & $\begin{array}{l}10(31.25) \\
28(43.75)\end{array}$ & $\begin{array}{l}0.33 \\
0.66\end{array}$ & 0.23 \\
\hline Sex & $\begin{array}{l}\text { Male } \\
\text { Female }\end{array}$ & $\begin{array}{l}18(42.86) \\
40(74.07)\end{array}$ & $\begin{array}{l}24(57.14) \\
14(25.93)\end{array}$ & $\begin{array}{l}0.43 \\
0.56 \\
\end{array}$ & $0.002^{* * *}$ \\
\hline Education & $\begin{array}{l}\text { Literate } \\
\text { Illiterate }\end{array}$ & $\begin{array}{l}58(69.88) \\
0(0)\end{array}$ & $\begin{array}{l}25(30.12) \\
13(100)\end{array}$ & $\begin{array}{l}0.86 \\
0.13\end{array}$ & $<0.001^{* * *}$ \\
\hline Occupation & $\begin{array}{l}\text { Employed } \\
\text { Unemployed }\end{array}$ & $\begin{array}{l}27(65.85) \\
31(56.36)\end{array}$ & $\begin{array}{l}14(34.15) \\
24(43.64)\end{array}$ & $\begin{array}{l}0.43 \\
0.57\end{array}$ & 0.34 \\
\hline Socio-economic class & $\begin{array}{l}\text { Upper caste } \\
\text { Lower caste }\end{array}$ & $\begin{array}{l}47(70.15) \\
11(37.93)\end{array}$ & $\begin{array}{l}20(29.85) \\
18(62.07)\end{array}$ & $\begin{array}{l}0.7 \\
0.30\end{array}$ & $0.03^{* * *}$ \\
\hline Ethnicity & $\begin{array}{l}\text { Upper caste } \\
\text { Relatively advantaged janajatis } \\
\text { Others* }\end{array}$ & $\begin{array}{l}38(66.67) \\
13(52) \\
7(50)\end{array}$ & $\begin{array}{l}19(33.33) \\
12(48) \\
7(50)\end{array}$ & $\begin{array}{l}0.59 \\
0.26 \\
0.14\end{array}$ & 0.31 \\
\hline Religion & $\begin{array}{l}\text { Hindu } \\
\text { Buddhist } \\
\text { Others }\end{array}$ & $\begin{array}{l}49(61.25) \\
8(72.73) \\
1(20) \\
\end{array}$ & $\begin{array}{l}31(38.75) \\
3(27.27) \\
4(80)\end{array}$ & $\begin{array}{l}0.83 \\
0.11 \\
0.05\end{array}$ & 0.12 \\
\hline Residential area & $\begin{array}{l}\text { Urban } \\
\text { Rural }\end{array}$ & $\begin{array}{l}45(64.29) \\
13(50)\end{array}$ & $\begin{array}{l}25(35.71) \\
13(50)\end{array}$ & $\begin{array}{l}0.73 \\
0.27\end{array}$ & 0.20 \\
\hline Awareness & $\begin{array}{l}\text { Yes } \\
\text { No }\end{array}$ & $\begin{array}{l}12(80) \\
46(56.79)\end{array}$ & $\begin{array}{l}3(20) \\
35(43.21)\end{array}$ & $\begin{array}{l}15 \\
0.84 \\
\end{array}$ & 0.09 \\
\hline Past history of MI & $\begin{array}{l}\text { Yes } \\
\text { No }\end{array}$ & $\begin{array}{l}4(40) \\
54(62.79)\end{array}$ & $\begin{array}{l}6(60) \\
32(37.21)\end{array}$ & $\begin{array}{l}0.10 \\
0.89\end{array}$ & 0.16 \\
\hline
\end{tabular}

Ethnicity $=*$, others in the ethnicity= dalit, disadvantaged janajati, religious minorities, disadvantaged non-dalit Terai caste group, Religion $={ }^{* *}$, Others $=$ muslim, Christian etc Significant $=* * *, a=$ chi square test 


\begin{tabular}{|c|c|c|c|c|c|}
\hline & \multirow[t]{2}{*}{ Variables } & \multicolumn{2}{|c|}{ Practice } & \multirow{2}{*}{ Total (\%) } & \multirow{2}{*}{ p-valuea } \\
\hline & & Good & Poor & & \\
\hline Age category & $\begin{array}{l}<50 \text { years } \\
>50 \text { years }\end{array}$ & $\begin{array}{l}21(65.63) \\
34(53.13)\end{array}$ & $\begin{array}{l}11(34.37) \\
30(46.87)\end{array}$ & $\begin{array}{l}0.33 \\
0.67\end{array}$ & 0.24 \\
\hline Sex & $\begin{array}{l}\text { Female } \\
\text { Male }\end{array}$ & $\begin{array}{l}26(61.90) \\
29(53.70) \\
\end{array}$ & $\begin{array}{l}16(38.09) \\
25(46.30) \\
\end{array}$ & $\begin{array}{l}0.43 \\
0.56 \\
\end{array}$ & 0.42 \\
\hline Residential area & $\begin{array}{l}\text { Urban } \\
\text { Rural }\end{array}$ & $\begin{array}{l}39(55.71) \\
16(61.54)\end{array}$ & $\begin{array}{l}31(44.29) \\
10(38.46)\end{array}$ & $\begin{array}{l}0.73 \\
0.27\end{array}$ & 0.60 \\
\hline Education & $\begin{array}{l}\text { Literate } \\
\text { Illiterate }\end{array}$ & $\begin{array}{l}50(60.24) \\
5(38.46)\end{array}$ & $\begin{array}{l}33(39.76) \\
8(61.54) \\
\end{array}$ & $\begin{array}{l}0.86 \\
0.13 \\
\end{array}$ & 0.14 \\
\hline $\begin{array}{l}\text { Socio-economic } \\
\text { status }\end{array}$ & $\begin{array}{l}\text { Upper class } \\
\text { Lower class }\end{array}$ & $\begin{array}{l}39(58.21) \\
16(55.17)\end{array}$ & $\begin{array}{l}28(41.79) \\
13(44.83) \\
\end{array}$ & $\begin{array}{l}0.7 \\
0.3\end{array}$ & 0.78 \\
\hline Ethnicity & $\begin{array}{l}\text { Upper class } \\
\text { Relatively advantaged Janajatis } \\
\text { Others* }\end{array}$ & $\begin{array}{l}38(66.67) \\
8(32) \\
9(64.29)\end{array}$ & $\begin{array}{l}19(33.33) \\
17(68) \\
5(35.71)\end{array}$ & $\begin{array}{l}0.6 \\
0.26 \\
0.14\end{array}$ & $0.012^{* * *}$ \\
\hline Awareness & $\begin{array}{l}\text { Yes } \\
\text { No }\end{array}$ & $\begin{array}{l}13(86.67) \\
42(51.85)\end{array}$ & $\begin{array}{l}2(13.33) \\
39(48.15) \\
\end{array}$ & $\begin{array}{l}0.16 \\
0.84\end{array}$ & $0.012^{* * *}$ \\
\hline
\end{tabular}

Ethnicity $={ }^{*}$, others in the ethnicity $=$ dalit, disadvantaged janajati, religious minorities, disadvantaged non-dalit Terai caste group, Significant $=* * *, a=$ chi square test

\section{DISCUSSION}

This study assessed level of knowledge and practice of hypertensive patients regarding prevention of MI, where more than one quarter $(34.4 \%)$ of participants were between the age of 55-65 years. In contrast, study carried out in the Eastern part of Nepal had only $20.8 \%$ participants of this age group. ${ }^{9}$ More than half $(56.3 \%)$ of the hypertensive participants were male in present study which is similar with the study population of Pokhara $(66.7 \%){ }^{7}$ About three fourth $(72.9 \%)$ of our study participants were living in urban area which is similar to study done in India. ${ }^{10}$ It may be due to our study area located in the capital city of Nepal. More than half of the participants (59.4\%) were of upper caste group which is contrast to the study of Eastern part of Nepal where disadvantaged janajatis were highest among hypertensives. ${ }^{9}$ This might be due to differential geographical location of the two studies. Similarly, highest number $83.33 \%$ of our participants were Hindu which is higher than previous study. ${ }^{9}$ Around $86 \%$ were literate in our study which is similar to $(80 \%)$ study conducted in a part of India. ${ }^{10}$ In the same manner, more than half of participants $(57.3 \%)$ were unemployed in our study which is higher than a study conducted in India (12.94\%). ${ }^{11}$ Moreover, half of our participants were in upper middle class whereas study in a part of India showed that $24.11 \%$ were from class II socioeconomic status. ${ }^{11}$ This might be due to different geography and different tools used for classification of socioeconomic status.

Nearly half of our participants $(49 \%)$ were overweight followed by $32.3 \%$ obese based on the World health organization (WHO) classification of BMI for Asian people. ${ }^{12}$ Whereas, $65 \%$ had BMI more than or equal to twenty-five in a similar study of India. ${ }^{11}$ We found that $89.6 \%$ were at risk of cardiovascular disease due to increased waist hip ratio on the basis of the cutoff point of the waist-hip ratio of WHO. In contrast, 39.4\% of hypertensive men had $\geq 0.85$ waist hip ratio and $50.8 \%$ of hypertensive women had $\geq 0.95$ waist hip ratio in Surat city of India. ${ }^{3}$

Moreover, this study identified around more than half (60.4\%) had high knowledge and 39.6\% had low knowledge about prevention of MI which is higher than study conducted in India which revealed $15.33 \%$ had good knowledge and $84.67 \%$ had poor knowledge of prevention of cardiovascular diseases. ${ }^{10}$ This observed difference might be due to different characteristics of study participants. This study also revealed high level knowledge among female $(74.07 \%)$ than male $(42.86 \%)$. As this study, did not analyzed educational and other characteristics based on gender so it needs to be explored. In contrast, mean score of knowledge was little bit higher in male (13.86) than in female (13.29) in a study conducted in India. ${ }^{10}$ Similarly, this study shows that the mean score of knowledge is 8.29 out of 12 total score, while mean score was three, range $(0-11)$ out of 15 in a similar study done in Pakistan. ${ }^{6}$ This shows that mean knowledge score is comparatively greater in our study. The differential result might be due to different tools used to assess knowledge in both study. On the other hand, more than half $(57.3 \%)$ of the hypertensive patients had good practice and $(42.7 \%)$ had poor practice of prevention of MI in our study. Study of Pakistan revealed that although three quarter of the total participants felt that the preventive practice of the Coronary Heart Disease was needed, implementation of that thought in their real life was largely lacking. ${ }^{6}$ Likewise, another study of Karachi, Pakistan revealed good level of knowledge regarding modifiable risk factors, however, that study dealt about knowledge of modifiable risk factors rather than about prevention of MI only and the participants were already diagnosed as MI so that might have influenced the knowledge level. ${ }^{13}$ In line with our study, the knowledge score of MI and Hypertension were $6 \pm 1$ and $11 \pm 1$ respectively in the study done in Pokhara. ${ }^{7}$ Likewise, previous study conducted among hypertensive patients in Tribhuvan University Teaching Hospital showed more than half of the participants had 50\% knowledge about disease and 54\% were giving more than $50 \%$ emphasis about self care to prevent the complication of hypertension ${ }^{14}$ which is similar to our findings. It might be due to similar study setting as both are central level referral hospital and other socio demographics characteristics of participants might be similar in both studies, however, tools of measurements were not alike. 
This is a small scale hospital cross sectional study which only included the hypertensive patients of OPD of Tertiary Cardiac Center of Nepal. So, we could not generalize our study findings in different settings was the limitation of the study.

\section{Conclusion}

This study showed that only around half of the participants had high level of knowledge and good practice. It also found that knowledge and practice are influenced by the gender, education, socio-economic status, ethnicity, and awareness. Thus, further awareness regarding prevention of MI needs to be provided to hypertensive patients and large scale study should be planned to identify the determinants of knowledge and practice of prevention of MI among hypertensive patients.

\section{REFERENCES}

1. Kearney PM, Whelton M, Reynolds K et.al. Global burden of hypertension: analysis of worldwide data. The Lancet. 2005;365(9455):217-23.

2. Goyal A,Yusuf S. The burden of disease in the Indian subcontinent. Indian J Med Res. 2006; 124:235-244

3. Gandhi S, Chaudhari, Bhuval R, Mallick K, Vasava B. Awareness and prevention of Myocardial Infarction and Hypertension in general population of Surat City. National Journal of Community Medicine. 2010;1(2).139.

4. David S. Celermajer, Clara K. Chow et al. Cardiovascular Disease in the Developing World. Journal of the American College of Cardiology 2012; 60 (14) :1207 1216.

5. Vaidya A, Pokharel PK, Nagesh S,et al. Prevalence of Coronary Heart Disease in the Urban Adult Males of Eastern Nepal: A population-based analytical cross-section study. Indian Heart J. 2009;61(4):341-7.

6. Jafary H F, Aslam F, Mahmud H,et al .Cardiovascular health knowledge and behavior in patient attendants at four tertiary care hospitals in Pakistan- a cause for concern. BMC Public Health.2005;5: 124. doi:10.1186/1471-2458$5-124$

7. Shankar PR, Partha P, Shenoy N, et al. Knowledge about heart attack and hypertension among individuals attending a cardiac camp in Pokhara city. Kathmandu University Medical Journal. 2015; 5 (2):273-278.

8. Gosh A. Modification of Kuppuswamy's Socioeconomic Status Scale in context to Nepal. Indian Pediatrics.2009;46:1104-1105

9. Bhandari B, Bhattarai M, Bhandari $M$, et al. Prevalence of other associated risk factors of Cardiovascular Disease among Hypertensive patients in Eastern Nepal. Nepalese Heart Journal 2014;11(1): 27-31

10. Choudhary M, Sharma k, Sodhi J. Knowledge Regarding Preventive Measures of Coronary Artery Disease among Patient Attending Out Patient Departments of Selected Hospital Of Ludhiana City. International Journal of Healthcare sciences. 2014;2(1):60-63.

11. Mahajan H, Kazi Y, Sharma B, Vlhal GD. Assessment of KAP, Risk Factors and Associated Co-Morbidities in Hypertensive Patients. IOSR-JDMS. 2012;1(2):6-1.

12. Organization $W H$. The Asia-Pacific perspective: redefining obesity and its treatment. Sydney: Health Communications Australia; 2000.

13. Khan S M, Jafary H F, Jafar H T, et al. Knowledge of modifiable risk factors of heart disease among patients with acute myocardial infarction in Karachi, Pakistan: a cross sectional study. BMC cardiovascular disorder.2006; 6:18.

14. Bhandari B, Bhattarai $M$, Jha N. Awareness of disease and self-care among hypertensive patients attending Tribhuvan University teaching hospital, Kathmandu, Nepal. Journal of Nobel Medical College.2012;1(2):29-35.
Cite this article as: Asmita Adhikari, Buna Bhandari. Awareness and Practice of Prevention of Myocardial Infarction among Hypertensive Patients Nepalese Heart Journal 2017; 14(1): 29-30 